\title{
Feeding habits of the Robber Frog Pristimantis paulodutrai (Bokermann, 1975) in northeastern Brazil
}

\author{
Thales Francisco S. S. Alves-dos-Santos ${ }^{1(0)}$, Lucas Rodriguez, Forti ${ }^{1,2}$ \& Marcelo Felgueiras Napoli ${ }^{2} *$ (i) \\ ${ }^{1}$ Universidade Federal da Bahia, Instituto de Biologia, Programa de Pós-Graduação em Ecologia: Teoria, \\ Aplicações e Valores, Rua Barão de Jeremoabo, Campus Universitário de Ondina, 40170-115, Salvador, BA, \\ Brasil. \\ ${ }^{2}$ Universidade Federal da Bahia, Instituto de Biologia, Rua Barão de Jeremoabo, Campus Universitário de \\ Ondina, 40170-115, Salvador, BA, Brasil. \\ *Corresponding author: Marcelo F. Napoli, e-mail: napoli@ufba.br
}

\author{
ALVES-DOS-SANTOS, T.F.S.S., FORTI, L.R., NAPOLI, M.F. Feeding habits of the Robber Frog Pristimantis \\ paulodutrai (Bokermann, 1975) in northeastern Brazil. Biota Neotropica 21(2): e20201098. \\ https://doi.org/10.1590/1676-0611-BN-2020-1098
}

\begin{abstract}
Studying feeding habits is crucial to understand complex predator-prey interactions. Even though anurans play a fundamental role in the control of arthropods populations, the diet of several Neotropical species is poorly known. We describe the frequency and occurrence of prey items and their dry mass in stomach contents of the Robber Frog Pristimantis paulodutrai in the north east of the state of Bahia, Brazil. Based on the stomach contents of 30 individuals, Araneae, Isopoda, and Formicidae were found to be the most important food items. The generalist diet of this frog, which seems to be phylogenetically conserved among Pristimantis, is likely to be linked to its ecological dominance in the habitats surveyed. Our study corroborates the high trophic relevance of Robber Frogs in tropical forests as generalist predators.

Keywords: Amphibia; Anura; Bahia; Craugastoridae; diet; predator-prey interaction.
\end{abstract}

\section{Hábitos alimentares da rã Pristimantis paulodutrai (Bokermann, 1975) no nordeste do Brasil}

Resumo: Estudar hábitos alimentares é crucial para entender as complexas interações predador-presa. Embora os anuros tenham papel fundamental no controle das populações de artrópodes, a dieta de várias espécies neotropicais é pouco conhecida. Descrevemos a frequência e a ocorrência de presas e sua massa seca no conteúdo estomacal da rã Pristimantis paulodutrai, no nordeste do estado da Bahia, Brasil. Com base no conteúdo estomacal de 30 indivíduos, Araneae, Isopoda e Formicidae foram os itens alimentares mais importantes. A dieta generalista desta rã, a qual parece ser conservada filogeneticamente entre os Pristimantis, provavelmente está ligada à sua dominância ecológica nos habitats pesquisados. Nosso estudo corrobora a alta relevância trófica dos Robber Frogs em florestas tropicais como predadores generalistas.

Palavras-chave: Amphibia; Anura; Bahia; Craugastoridae; dieta; interação predador-presa. 


\section{Introduction}

While studies of feeding habits of anurans have been increasing in number (e.g., Ortega et al. 2005, Forti et al. 2011, Solé et al. 2019), the relationship between frogs and their preys is still little known. Descriptive studies are fundamental to reveal complex predator-prey interactions and to determine the role of anurans in ecosystems (Hocking \& Babbitt 2014). The diet of frogs is particularly affected by their foraging behaviour and the characteristics of microhabitats (Toft 1995).

The genus Pristimantis Jiménez de la Espada, 1870 comprises 566 species, distributed from southern Central America to the Brazilian Atlantic Forest (Frost 2021). Most members of this genus are generalist predators (Arroyo et al. 2008, Garcia-R et al. 2015, Gutiérrez-Cárdenas et al. 2016). Nevertheless, knowledge about the natural history of these direct-developing frogs is still incipient, and the diet of several species, among them Pristimantis paulodutrai (Bokermann, 1975), which is the subject of our study, remains unknown.

The frog P. paulodutrai is restricted to the Atlantic Forest in Bahia state (Trevisan et al. 2020), and it is considered the most abundant and spatially distributed anuran species from coastal forests of northern Bahia state (Bastazini et al. 2007). In this study we aimed to identify the diet composition of this species, and given its ecological dominance among other amphibian species, we expected to find a rich assemblage of consumed preys. Yet, under an exploratory approach, we seek spatially structured feeding patterns for P. paulodutrai considering the main environmental landscape units in the study area.

\section{Material and Methods}

We examined 90 adult specimens of $P$. paulodutrai deposited in the Natural History Museum of the Federal University of Bahia (UFBA), collected by Bastazini et al. (2007) and previously used for ecologic, taxonomic, morphometric, and/or cytogenetic studies on the genus Pristimantis (e.g., Bastazini et al. 2007, Napoli et al. 2009, Dabés et al. 2012, Trevisan et al. 2020). The specimens were collected in a coastal Atlantic Forest area (a 500 hectares private conservation unit named Reserva Sapiranga, $12^{\circ} 33^{\prime} 59^{\prime}$ 'S, 38॰02' $18^{\prime \prime} \mathrm{W}, 20 \mathrm{~m}$ a.s.1, WGS84 datum) and in coastal sandplains (restinga environment at Praia do Forte, $12^{\circ} 34^{\prime} 12^{\prime}$ 'S, 38 $00^{\circ} 04^{\prime \prime} \mathrm{W}, 10 \mathrm{~m}$ a.s.1., WGS84 datum), both in the municipality of Mata de São João, state of Bahia, Brazil. The specimens were sampled in four distinct habitats (Bastazini et al. 2007): in Reserva Sapiranga, forested environments containing (1) springs, streams, and rivers, and (2) areas without bodies of water on the ground and with less than 20 tank bromeliads in a sample unit of $60 \times 25 \mathrm{~m}$; in the restinga of Praia do Forte, (3) sandy soil covered by many shrubs and terrestrial tank bromeliads under direct sunlight $(>100$ bromeliads per sample unit), which is contiguous with (4) a riparian forest that surrounds a lake formed by the freshwater Timeantube river, the latter filled with emergent vegetation. Detailed description of the environment, sampling units, sampling methods, and vouchered specimens were provided by Bastazini et al. (2007). During fieldwork voucher specimens of P. paulodutrai (referred by the authors as Eleutherodactylus ramagii) were kept alive in containers with ice up to six hours to reduce the speed of digestion of stomach contents (T.F.S.S. Alves-dos-Santos, personal observation). Prey availability was not measured during the sampling period and, therefore, we did not calculate electivity of prey categories (comparison between consumed and available food items). Specimens examined are housed in the amphibian collection of the Natural History Museum of the Federal University of Bahia (UFBA) (Appendix 1).

We dissected individuals and examined their stomach content using an Olympus stereomicroscope. Only adult males were evaluated because females and juveniles were rare in the samples. The prey items were grouped into orders (except for Annelida, Gastropoda, and Formicidae). We followed the methods of Magnusson et al. (2003) to determine the dry mass and to estimate the contribution of each prey item. The total dry mass of each prey item was recorded to the nearest $0.1 \mathrm{mg}$, and each food item was dried in a $50^{\circ} \mathrm{C}$ stove for two hours. We assigned a mass value of $0.1 \mathrm{mg}$ for prey categories if their dry mass was less than the precision of the instrument $(1 \mathrm{mg})$ to record the prey category in the diet without influencing the contribution of the most important prey categories.

We calculated the proportion of biomass $(\mathrm{M})$ and frequency $(\mathrm{F})$ of prey categories for each stomach individually and then averaged these proportions for the stomachs that were full. This procedure resulted in proportional data, which avoids the bias originating from the anurans' uneven body size (Evans \& Lampo 1996) and the biomass of the stomach content and confers the same importance to all specimens (Smith et al. 2004). The proportion of occurrence (O) of each consumed prey category was calculated as the number of stomachs with a prey category averaged for the total number of full stomachs. Items with the highest index of relative importance (IRI) was considered the most important prey categories in the diet of $P$. paulodutrai (Pinkas et al. 1971). We used the IRI (\%) values in a hierarchical clustering method, under an exploratory approach, to seek and display the strongest structure of feeding patterns for $P$. paulodutrai considering four habitats identified by Bastazini et al. (2007), using the Ward's method solution (Ward's minimum variance method; Ward 1963) and Euclidean distance measure as distance metric. The source data matrix consists of four lines (environment types) and 11 columns (prey categories). The analysis was performed using the software Statistica ver. 13 (TIBCO 2018).

\section{Results and Discussion}

We obtained 30 adult males with full stomachs, containing 49 food items $(\bar{x}=1.6 \mathrm{item} / \mathrm{stomach}$; total mass $=0.10724 \mathrm{~g})$ belonging to 11 prey categories (Figure 1, Table 1). The following prey categories had the largest (over 10\%) proportions of occurrence $(\mathrm{O})$ : Araneae (43.3\%), Formicidae (23.3\%), Isopoda (20.0\%), and Coleoptera (16.7\%). Orthoptera, Isopoda, Araneae, and "Larvae" had the largest M $(24.2 \%, 21.5 \%, 16.7 \%$, and $12.5 \%$, respectively), although the former was consumed by only three specimens of P. paulodutrai (10\%) and Araneae by 13 specimens (43.3\%). Coleoptera and Isopoda contributed with similar frequencies $(16.7 \%$ and $20.0 \%$, respectively), but with different mass contributions ( $8.3 \%$ and $21.5 \%$, respectively); the O of "larvae" was smaller than in Coleoptera (10\% and $16.7 \%$, respectively), but with higher $\mathrm{M}(12.5 \%$ and $8.3 \%$, respectively). The most important prey categories (index of relative importance $>10 \%$ ) consumed by P. paulodutrai were Araneae (46.6\%), Isopoda (16.1\%), and Formicidae (12.4\%) (Figure 1d, Table 2).

The high number of empty stomachs from adult males of $P$. paulodutrai ( $66 \%$ ) could be explained due to all individuals have been captured while reproductively active. The impact of calling behavior on male foraging success was already reported for $E$. coqui, which considerably reduce its foraging activity while exhibit to potential 

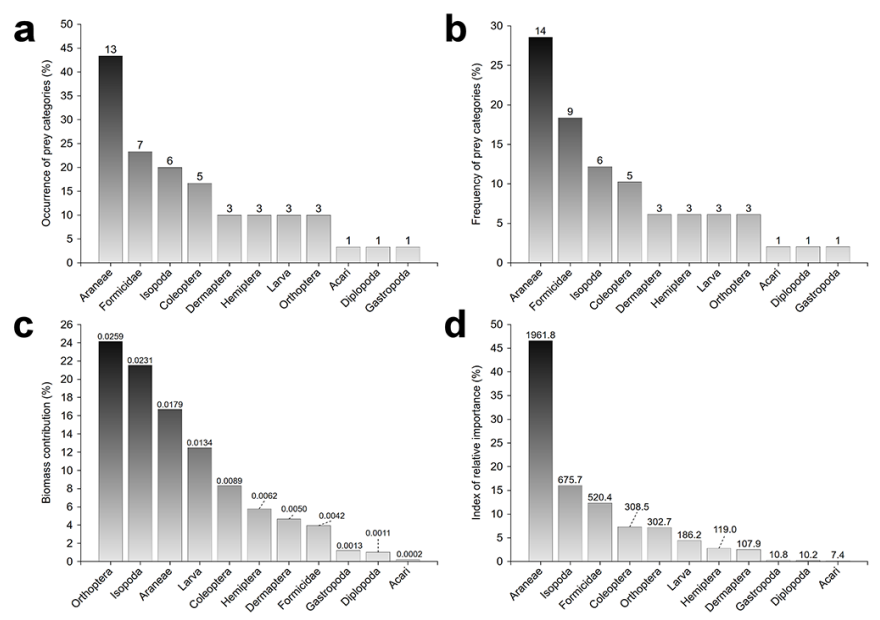

Figure 1. Prey categories in the diet of Pristimantis paulodutrai from a restinga area in the municipality of Mata de São João, state of Bahia, Brazil. (a) percentage of occurrence of each consumed alimentary category (number of stomachs with an alimentary category averaged for the total number of non-empty stomachs); (b) average percentage of prey categories; (c) average percentage of biomass contribution; and (d) IRI\%, index of relative importance (Pinkas 1971). Numbers at the top of columns represent non-transformed values sexual partners (Woolbright \& Stewart 1987). In this species, males usually start foraging after midnight, when calling activity is ceased (Woolbright 1985, Woolbright \& Stewart 1987). Therefore, temporal sampling bias could also contribute to explain empty stomachs in part of P. paulodutrai adult males because all of them were captured by active search at night from 1800 to $2400 \mathrm{~h}$ (Bastazini et al. 2007), assumed here as the period of their highest calling activity.

The hierarchical clustering analysis using IRI (\%) values was able to express structure in feeding patterns for P. paulodutrai along the landscape (Figure 2, Table 2), gathering two habitat groups: (1) a group composed of forested environments with water bodies on the ground (habitats 1 and 4), and (2) a group of environments deprived of water bodies on the ground, combining forested zones and open restinga habitats with terrestrial tank bromeliads (habitats 2 and 3). Foraging success in amphibians is known to be dependent of local climatic conditions (seasonal and/or daily fluctuations) and one possible consequence is the reduction of movement and foraging activity due to water-conserving posture in situations of osmotic stress (Pough et al. 1983, Woolbright \& Stewart 1987, Wells 2007). Therefore, we suppose that variations in qualitative and/or quantitative prey availability throughout the day, combined with periods of low motility and foraging,

Table 1. Prey categories in the diet of Pristimantis paulodutrai within four habitats of a restinga landscape in the municipality of Mata de São João, state of Bahia, Brazil. Habitats are ordered following clustering structure resulted from Ward's method solution (Figure 2). An empty cell indicates a non-available prey category in habitat. Values in parentheses correspond to non-transformed data. Reserva Sapiranga: habitat 1, forested environments containing springs, streams, and rivers; habitat 2, forested environments without bodies of water on the ground and with less than 20 tank bromeliads in a sample unit of $60 \mathrm{x}$ $25 \mathrm{~m}$. Praia do Forte: habitat 3, sandy soil covered by many shrubs and terrestrial tank bromeliads under direct sunlight ( $>100$ bromeliads per sample unit); and habitat 4, riparian forest that surrounds a lake formed by the freshwater Timeantube river, the latter filled with emergent vegetation.

\begin{tabular}{|c|c|c|c|c|c|c|c|c|c|c|c|c|}
\hline & \multicolumn{3}{|c|}{ Habitat 4} & \multicolumn{3}{|c|}{ Habitat 1} & \multicolumn{3}{|c|}{ Habitat 2} & \multicolumn{3}{|c|}{ Habitat 3} \\
\hline & $\% O$ & $\% \mathbf{M}$ & $\% F$ & $\% O$ & $\% \mathbf{M}$ & $\% F$ & $\%$ & $\% \mathbf{M}$ & $\% F$ & $\% O$ & $\% \mathbf{M}$ & $\% F$ \\
\hline Araneae & 25.0 & 14.4 & 25.0 & 44.4 & 9.9 & 25.0 & 42.9 & 40.1 & 33.3 & 66.7 & 21.5 & 31.3 \\
\hline \multirow[t]{2}{*}{ Formicidae } & 12.5 & 4.6 & 12.5 & 22.2 & 0.9 & 18.8 & 14.3 & 7.0 & 11.1 & 50.0 & 11.7 & 25.0 \\
\hline & (1) & $(0.00080)$ & (1) & (2) & $(0.00051)$ & (3) & (1) & $(0.00110)$ & (1) & (3) & $(0.00181)$ & (4) \\
\hline Coleoptera & (3) & $(0.00780)$ & (3) & & & & (2) & $(0.00111)$ & (2) & & & \\
\hline \multirow[t]{2}{*}{ Isopoda } & 25.0 & 36.2 & 25.0 & 44.4 & 28.6 & 25.0 & & & & & & \\
\hline & (2) & $(0.00630)$ & (2) & (4) & $(0.01680)$ & (4) & & & & & & \\
\hline \multirow[t]{2}{*}{ Dermaptera } & & & & 11.1 & 1.5 & 6.3 & & & & 33.3 & 26.6 & 12.5 \\
\hline & & & & (1) & $(0.00090)$ & (1) & & & & (2) & $(0.00410)$ & (2) \\
\hline Larva & & & & (2) & $(0.01280)$ & (2) & & & & (1) & $(0.00060)$ & (1) \\
\hline \multirow[t]{2}{*}{ Orthoptera } & & & & 22.2 & 37.3 & 12.5 & 14.3 & 25.5 & 11.1 & & & \\
\hline & & & & (2) & $(0.02190)$ & (2) & (1) & $(0.00400)$ & (1) & & & \\
\hline \multirow[t]{2}{*}{ Acari } & & & & & & & & & & 16.7 & 1.3 & 6.3 \\
\hline & & & & & & & & & & (1) & $(0.00020)$ & (1) \\
\hline \multirow[t]{2}{*}{ Diplopoda } & & & & & & & & & & 16.7 & 7.1 & 6.3 \\
\hline & & & & & & & & & & (1) & $(0.00110)$ & (1) \\
\hline Gastropoda & & & & & & & & & & 16.7 & 8.4 & 6.3 \\
\hline
\end{tabular}


Table 2. Index of relative importance - IRI (Pinkas et al. 1971) calculated for alimentary categories eaten by Pristimantis paulodutrai within four habitats of a restinga landscape in the municipality of Mata de São João, state of Bahia, Brazil. Habitats are ordered following clustering structure resulted from the Ward's method solution (Figure 2). An empty cell indicates a non-available prey category in habitat. Reserva Sapiranga: habitat 1, forested environments containing springs, streams, and rivers; habitat 2, forested environments without bodies of water on the ground and with less than 20 tank bromeliads in a sample unit of $60 \times 25 \mathrm{~m}$. Praia do Forte: habitat 3 , sandy soil covered by many shrubs and terrestrial tank bromeliads under direct sunlight $(>100$ bromeliads per sample unit); and habitat 4, riparian forest that surrounds a lake formed by the freshwater Timeantube river, the latter filled with emergent vegetation

\begin{tabular}{|c|c|c|c|c|c|c|c|c|c|c|}
\hline & \multicolumn{2}{|c|}{ Overall Restinga } & \multicolumn{2}{|c|}{ Habitat 4} & \multicolumn{2}{|c|}{ Habitat 1} & \multicolumn{2}{|c|}{ Habitat 2} & \multicolumn{2}{|c|}{ Habitat 3} \\
\hline & IRI & IRI\% & IRI & IRI\% & IRI & IRI\% & IRI & IRI\% & IRI & IRI\% \\
\hline Araneae & 1961.80 & 46.59 & 984.20 & 16.92 & 1550.18 & 24.51 & 3147.22 & 52.61 & 3514.38 & 44.80 \\
\hline Formicidae & 520.39 & 12.36 & 213.72 & 3.68 & 435.97 & 6.89 & 258.76 & 4.33 & 1836.90 & 23.41 \\
\hline Coleoptera & 308.54 & 7.33 & 3087.28 & 53.09 & & & 836.79 & 13.99 & & \\
\hline Orthoptera & 302.74 & 7.19 & & & 1106.71 & 17.50 & 522.47 & 8.73 & & \\
\hline Hemiptera & 119.04 & 2.83 & & & & & 1216.90 & 20.34 & 428.42 & 5.46 \\
\hline Dermaptera & 107.85 & 2.56 & & & 86.48 & 1.37 & & & 1302.96 & 16.61 \\
\hline Gastropoda & 10.84 & 0.26 & & & & & & & 244.68 & 3.12 \\
\hline Diplopoda & 10.22 & 0.24 & & & & & & & 223.06 & 2.84 \\
\hline Acari & 7.42 & 0.18 & & & & & & & 125.78 & 1.60 \\
\hline
\end{tabular}

could contribute to different prey consumption by P. paulodutrai within distinct habitats. Furthermore, distinct composition and abundance of prey items between habitats could be argued as an explanation for the obtained results but these data were not acquired and, therefore, we cannot test if prey availability or frog's prey preference are able to explain our results.

Some Pristimantis species and other Brachycephaloidea are considered sit-and-wait foragers and not ant specialists (Toft 1981). In our study, $P$. paulodutrai had a varied diet (11 prey categories), which is more typical of an active forager's profile (Duellman \& Trueb 1994), with Formicidae being only its third most important prey category. Such high diversity of consumed preys followed the general feeding pattern of related species (e.g., Arroyo et al. 2008, Garcia-R et al. 2015, Gutiérrez-Cárdenas et al. 2016). We conclude that P. paulodutrai, as other common species, is not a diet specialist frog, which supports its large dominance within the studied landscape.

The numerical and spatial dominance of P. paulodutrai over other species in the study area could be partially explained by the ability of this common frog to prey on different groups of arthropods. While the spatial distribution of specialist predators is affected by limited prey availability, generalists may have a flexible distribution, with the availability of prey being a weaker spatial predictor (Giaretta et al. 1998, Santos et al. 2004). Although prey availability does not seem to be an important factor in restricting the spatial distribution of P. paulodutrai, this hypothesis must be tested in the future using an electivity analysis.

Pristimantis paulodutrai is a plastic species concerning water absorption under different osmotic stresses (e.g., low rates of dehydration and high rates of rehydration from water), which may favour its dominance in dry environments (Dabés et al. 2012). In addition, these frogs have direct development and terrestrial breeding (Napoli et al. 2009), which do not limit their distribution to the proximity of water bodies. The combination of these features with a generalist diet can explain the wide spatial distribution of P. paulodutrai.

These results contribute to our knowledge about the feeding habits of a Neotropical frog species, expand the scientific comprehension of

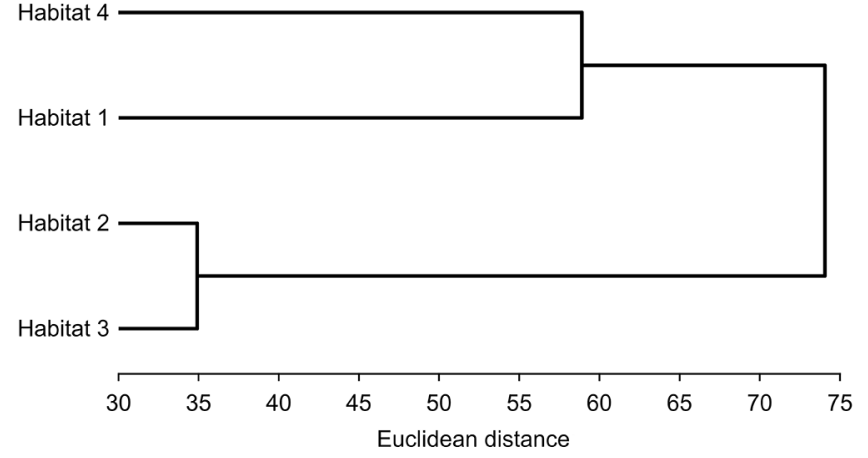

Figure 2. Hierarchical clustering analysis (Ward's method) on the Index of Relative Importance (IRI \%) (Pinkas 1971) calculated for alimentary categories eaten by Pristimantis paulodutrai in four different habitats of a restinga area in the municipality of Mata de São João, state of Bahia, Brazil. Reserva Sapiranga: habitat 1 , forested environments containing springs, streams, and rivers; habitat 2 , forested environments without bodies of water on the ground and with less than 20 tank bromeliads in a sample unit of $60 \times 25 \mathrm{~m}$. Praia do Forte: habitat 3, sandy soil covered by many shrubs and terrestrial tank bromeliads under direct sunlight $(>$ 100 bromeliads per sample unit); and habitat 4, riparian forest that surrounds a lake formed by the freshwater Timeantube river, the latter filled with emergent vegetation

the interaction between anurans and their preys, and provide additional insights to the spatial distribution of $P$. paulodutrai.

\section{Acknowledgments}

We are grateful to A. Camacho, A. Mendonça, A.L. Xavier, J.R. Bastazini, C.V. Bastazini, C. Macedo, M. Camardelli, P.M. Fonseca, R. Abreu, and W. Fahing for the excellent field assistance; to P.L.B. Rocha, W. Klein, M. Solé and J. Szabo for the valuable comments on previous versions of the manuscript, and to two anonymous reviewers from Biota Neotropica journal. TFSSA thanks the Coordenação de Aperfeiçoamento de Pessoal de Ensino Superior (CAPES) and the Programa de Capacitação para o Ensino Superior (PROCES) for fellowships. MFN acknowledges the Conselho Nacional de 
Desenvolvimento Científico e Tecnológico (CNPq) for productivity grant (\#310490/2018-9). LRF is grateful to the CNPq for fellowship (\#150041/2017-9) and to the CAPES for his current post-doctoral fellowship. We thank the Instituto Brasileiro do Meio Ambiente e dos Recursos Naturais Renováveis (IBAMA/RAN) for collection permits (license numbers 02006.002336/03-26 and 0210.000812/05-84).

\section{Author Contributions}

Thales Francisco S. S. Alves-dos-Santos: Substantial contribution in the concept and design of the study; contribution to data collection; contribution to data analysis and interpretation; contribution to manuscript preparation; contribution to critical revision, adding intellectual content.

Lucas Rodriguez Forti: Contribution to manuscript preparation; contribution to critical revision, adding intellectual content.

Marcelo Felgueiras Napoli: Substantial contribution in the concept and design of the study; contribution to data analysis and interpretation; contribution to manuscript preparation; contribution to critical revision, adding intellectual content.

\section{Conflicts of Interest}

The authors declares that they have no conflict of interest related to the publication of this manuscript.

\section{Ethics}

The specimens were collected with authorizations from the Instituto Brasileiro do Meio Ambiente e dos Recursos Naturais Renováveis (IBAMA/RAN, license numbers 02006.002336/03-26 and 0210.000812/05-84).

\section{Data availability}

All specimens used in this study are housed at the Amphibian Collection of the Natural History Museum of the Federal University of Bahia, Salvador, Bahia, Brazil, a scientific collection of a public institution (Appendix 1). Quantitative data used in hierarchical clustering analysis are available in Table 2.

\section{Supplementary Material}

The following online material is available for this article: Appendix 1

\section{References}

ARROYO, S.B., SERRANO-CARDOZO, V.H. \& RAMIREZ-PINILLA, M.P. 2008. Diet, microhabitat and time of activity in a Pristimantis (Anura, Strabomantidae) assemblage. Phyllomedusa, j. herpetol. 7;109-119. doi:10.11606/issn.2316-9079.v7i2p109-119

BASTAZINI, C.V., MUNDURUCA, J.F.V., ROCHA, P.L.B. \& NAPOLI, M.F. 2007. Which environmental variables better explain changes in anuran community composition? A case study in the Restinga of Mata de São João, Bahia, Brazil. Herpetologica 63:459-471. doi:10.1655/00180831(2007)63[459:WEVBEC]2.0.CO;2
DABÉS, L., BONFIM, V.M.G., NAPOLI, M.F. \& KLEIN, W. 2012. Water balance and spatial distribution of an anuran community from Brazil. Herpetologica 68:443-455. doi:10.1655/HERPETOLOGICA-D-10-00058

DUELLMAN, W.E. \& TRUEB, L. 1994. Biology of Amphibians. The Johns Hopkins University Press, Baltimore.

EVANS, M. \& LAMPO, M. 1996. Diet of Bufo marinus in Venezuela. J. herpetol. 30:73-76. doi:10.2307/1564710

FORTI, L.R., TISSIANI, A.S.O., MOTT, T. \& STRÜSSMANN, C. 2011. Diet of Ameerega braccata (Steindachner, 1864) (Anura: Dentrobatidae) from Chapada dos Guimarães and Cuiabá, Mato Grosso State, Brazil. Braz. J. Biol. 71:189-196. doi:10.1590/S1519-69842011000100027

FROST, D.R. 2021. Amphibian Species of the World: An Online Reference. Version 6.1. (Access January 15, 2021). Electronic Database accessible at: https://amphibiansoftheworld.amnh.org/index.php. American Museum of Natural History, New York. doi:10.5531/db.vz.0001

GARCIA-R, J.C., POSSO-GÓMEZ, C.E. \& CÁRDENAS-HENAO, H. 2015. Diet of direct-developing frogs (Anura: Craugastoridae: Pristimantis) from the Andes of western Colombia. Acta Biol. Colomb. 20:79-87. doi:10.15446/ abc.v20n 1.41153

GIARETTA, A.A., ARAÚJO, M.S., MEDEIROS, H.F. \& FACURE, K.G. 1998. Food habits and ontogenetic diet shifts of the litter dwelling frog Proceratophrys boiei (Wied). Rev. Bras. Zool. 15:385-388. doi:10.1590/ S0101-81751998000200011

GUTIÉRREZ-CÁRDENAS, P.D.A., CASTILLO, K., MARTÍNEZ, D., ROCHA, C.F.D. \& ROJAS-RIVERA, M.A. 2016. Trophic ecology of Pristimantis labiosus (Anura: Craugastoridae) from South-Western Colombia. NorthWest. J. Zool. 12:102-109. https://biozoojournals.ro/nwjz/content/v12n1/ nwjz_e151509_Gutierrez.pdf (last access on 30/07/2020)

HOCKING, D.J. \& BABBITT, K.J. 2014. Amphibian contributions to ecosystem services. Herpetol. Conserv. Bio. 9:1-17. http://www.herpconbio.org/ Volume_9/Issue_1/Hocking_Babbitt_2014.pdf (last access on 30/07/2020)

MAGNUSSON, W.E., LIMA, A.P., SILVA, W.A. \& ARAÚJO, M.C. 2003. Use of geometric forms to estimate volume of invertebrates in ecological studies of dietary overlap. Copeia 2003:13-19. doi:10.1643/00458511(2003)003[0013:UOGFTE]2.0.CO;2

NAPOLI, M.F., ANANIAS, F., FONSECA, P.M. \& SILVA, A.P.Z. 2009. Morphological and karyotypic contributions for a better taxonomic definition of the frog Ischnocnema ramagii (Boulenger, 1888) (Anura, Brachycephalidae). South am. j. herpetol. 4:164-172. doi:10.2994/057.004.0207

ORTEGA, J.E., SERRANO, V.H. \& PINILLA, M.P.R. 2005. Diet composition and microhabitat of Eleutherodactylus johnstonei in an introduced population at Bucaramanga City, Colombia. Herpetol. rev. 36:238-241. https://www.dropbox.com/s/64t81mvnu31xvqs/HR\%202005.36.3new. pdf?dl=1 (last access on 30/07/2020)

PINKAS, L., OLIPHANT, M.S., IVERSON, I.L.K. 1971. Food habits of albacore, bluefin tuna and bonito in California waters. Fish Bulletin 152:1-105.

POUGH, F.H., TAIGEN, T.L., STEWART, M.M. \& BRUSSARD, P.F. 1983. Behavioral modification of evaporative water loss by a Puerto Rican frog. Ecology 64:244-252. doi:10.2307/1937072

SANTOS, E.M., ALMEIDA, A.V. \& VASCONCELOS, S.D. 2004. Feeding habits of six anuran (Amphibia: Anura) species in a rainforest fragment in Northeastern Brazil. Iheringia, Série Zoologia, 94:433-438. doi:10.1590/ S0073-47212004000400014

SMITH, L.M., GRAY, M. J. \& QUARLES, A. 2004. Diets of newly metamorphosed amphibians in west Texas Playas. Southwest. Nat. 49:257263. doi:10.1894/0038-4909(2004)049\%3C0257:DONMAI\%3E2.0.CO;2

SOLÉ, M., DIAS, I.R., RODRIGUES, E.A.S., MARCIANO-JR, E., BRANCO, S.M.J. \& RÖDDER, D. 2019. Diet of Leptodactylus spixi (Anura: Leptodactylidae) from a cacao plantation in southern Bahia, Brazil. NorthWest. J. Zool. 15:62-66. https://biozoojournals.ro/nwjz/content/v15n1/ nwjz_e181501_Sole.pdf (last access on 30/07/2020)

TIBCO Software Inc. 2018. Statistica (data analysis software system), version 13. http://tibco.com.

TOFT, C.A. 1981. Feeding ecology of Panamanian litter anurans: patterns in diet and foraging mode. J. herpetol. 15:139-144. doi:10.2307/1563372 
Alves-dos-Santos, T.F.S.S. et al.

TOFT, C.A. 1995. Evolution of diet specialization in poison-dart frogs (Dendrobatidae). Herpetologica 51:202-216.

TREVISAN, C.C., BATALHA-FILHO, H., GARDA, A.A., MENEZES, L., DIAS, I.R., SOLÉ, M., CANEDO, C., JUNCÁ, F.A. \& NAPOLI, M.F. 2020. Cryptic diversity and ancient diversification in the northern Atlantic Forest Pristimantis (Amphibia, Anura, Craugastoridae). Mol. phylogenet. evol. 148:106811. doi:10.1016/j.ympev.2020.106811

WARD, J.H. 1963. Hierarchical grouping to optimize an objective function. J Am Stat Assoc 58:236.

WELLS, K.D. 2007. The ecology and behavior of amphibians. University of Chicago Press, Chicago.
WOOLBRIGHT, L. 1985. Patterns of nocturnal movement and calling by the Tropical frog Eleutherodactylus coqui. Herpetologica 41(1):1-9.

WOOLBRIGHT, L. \& STEWART, M. 1987. Foraging success of the Tropical frog, Eleutherodactylus coqui: The cost of calling. Copeia 1987(1):69-75. doi: $10.2307 / 1446039$

Received: 05/08/2020

Revised: 15/01/2021

Accepted: 14/02/2021

Published online: 07/04/2021 